\title{
Firm characteristics and Biological Asset Disclosure on Agricultural Firms
}

\author{
Anita Carolina ${ }^{1^{*}}$, Fariyana Kusumawati ${ }^{2}$, Khy'sh Nusri Leapatra Chamalinda $^{3}$ \\ 1,2,3 Faculty of Business and Economics, Universitas Trunojoyo Madura, \\ Jalan Raya Telang PO. BOX 2 Kamal, Bangkalan 69162, Indonesia \\ *Corresponding author; Email: 1"nietaff1@gmail.com, ${ }^{2 k f a r i y a n a @ g m a i l . c o m, ~}{ }^{3 k}$ khyshnusri92@gmail.com
}

\begin{abstract}
Agriculture firms are facing challenges on applying the Statement of Financial Accounting Standards (PSAK) 69 which regulates the recognition, measurement, disclosure, presentation and reporting biological assets because of the unique trait of biological assets. This research aims to decide the factors that influence the biological asset disclosure by testing the effect of leverage, profitability, liquidity, firm's growth, biological assets' intensity, firm size, type of auditor, and listing status. The samples used in this research are the agriculture firms listed on the Indonesia Stock Exchange (IDX) between 2016 and 2018. The data are collected from the auditor financial statement. This research uses a quantitative method with multiple linear regression analysis. The conclusion is that the intensity of biological asset influences the biological asset disclosure, while leverage, profitability, liquidity, firm's growth, firm size, type of auditor, and listing status do not influence the biological asset disclosure. This research contributes as literature for academics, gives knowledge about agriculture firm's problems for the standard compiler, and improving the agriculture firms' obediency in disclosing their biological asset following the PSAK 69.
\end{abstract}

Keywords: Biological asset; disclosure; PSAK 69; firm characteristics.

\section{INTRODUCTION}

Agriculture firms are facing a complexity on recognition, measurement, disclosure, presentation, and reporting their owned biological assets. The agriculture sector has an important role in the global economic growth, however, the accounting treatment for the agriculture activity is getting less attention in the accounting standards which is more focused on the production activity, marketing, and tax reporting [32]. Therefore, the accounting treatment about biological asset must be understood and adhered by the agriculture firms [61].

In Indonesia, the agriculture sector is contributing to economic growth. Since 2014 until 2018 there is an improvement in the national export with a percentage of $29 \%$, or 500 trillion rupiahs [12]. PSAK 69 regulates the biological asset so that it can be used as the guideline for agriculture firms in arranging the financial statement. Financial Accounting Standards Board (DSAK) has approved the PSAK 69 on January 1st, 2017 and applied on 2018. PSAK 69 has fully adopted the International Accounting Standards (IAS) 41 agriculture.

Firms that disclose adequate information about the biological asset in their financial statement is deemed obedient to the financial accounting standards [75]. The information revealed on the financial statement has a crucial role for the firm which can reflect their firm's performance. The disclosure of the financial statement is defined as the delivery of various economic information by the firms which portrays the firm's business performance and positioning that consist of information about both financial and non-financial condition, also information about both quantitative and nonquantitative notes [62] [74]. The disclosure of information from the management is a strategic tool which can improve a firm's ability to obtain capital with a low cost [41]. A firm's annual financial statement can be used as one of the means to disclose information and has a function as a firm's performance monitoring tool [78]. The biological asset disclosure on the financial statement will improve the financial statement quality and benefit [75]. The authorized institution to make the financial regulation obliged firms to make a financial statement which reveals real information about the conducted activities to minimalize information asymmetry between management and shareholders [42]. From the viewpoint of the agency theory, information asymmetry and conflict of interest between manager and shareholders could inflict agency costs [46]. Therefore, to reduce the agency costs, manager discloses more information to the shareholders [79].

Based on the signalling theory, the problem of information asymmetry could be reduced with the information disclosure from the management [3], [51], [56], [66]. The disclosed information on the 
firm's financial statement gives good signals directly and indirectly to the financial statement users regarding what the firm wants to achieve, the firm's intention, as well as the motive of the firm's action [63], [72]. Like wise with the stakeholder theory which sees that for firms to achieve their goals, they must give special attention to the stakeholders as a party who has an interest in the firm [34]. Hence, a firm must fulfil the stakeholder's interests with disclosing the information about the firm's real activities [25], [52], [81].

The academic interest on the issue of the biological asset disclosure has been indicated with the development and testing of research model which is related with the factors influencing the biological asset disclosure [28], [37], [38], [83]. The research [28] investigates the relationship between the intensity of biological, firm size, type of auditor, ownership concentration, and profitability towards the biological asset disclosure. The research [37] analyzes the effect of biological intensity, ownership concentration, size, auditor type and international stakeholders towards the biological asset disclosure. The research [37] tests the disclosure level with firm-level determinants (biological assets intensity, ownership concentration, firm size, auditor type, internationalization level, listing status, and profitability), sector, country-level determinant and legal status. In the research [83], tests the relationship between the biological asset disclosure with the intensity of biological asset, firm size, ownership concentration, and auditor type.

This research aims to investigate the factors that are influencing the biological asset disclosure based on PSAK 69 on agriculture firms holistically (a whole) by combining the firm characteristics variables such as leverage, profitability, liquidity, firm's growth, biological asset intensity, firm size, auditor type, and listing status on agricultural firms which are listed on Indonesia Stock Exchange (IDX) between 2016 and 2018. The practice of PSAK 69 on agriculture firms is facing several challenges, especially regarding the measurement method complexity using fair value and detailed disclosure about a biological asset which is measured by their fair value. It is why research about the biological asset disclosure needs to be studied more. To add more, there is an inconsistency on the research result regarding biological asset disclosure.

Different from the research of [28] and [83], this research adds the leverage, profitability, firm's growth, liquidity, and listing status variables. Other than that, the firm's financial statement used in this research is from between 2016 and 2018. This research also fulfils the recommendation given by [37] and [38] by adding the variables leverage, liquidity, and firm's growth.
This research contributes several things, firstly, it is useful for academics since it can increase the number of scientific literature about biological assets. Secondly, for standards compilers, it can give them portrait and understanding regarding the aspects that become a problem for agriculture firms, thus it can be a guideline or consideration in the future. As for the third, it is useful for firms since it can give a portrait about the biological asset disclosure, thus it can improve the obediency of firms so it can fit the PSAK 69. Therefore, this research is beneficial for the regulator, accounting standards maker, firms, and shareholders that have interests towards the information disclosure, especially the biological asset disclosure.

In the next part, this research discusses the literature framework, hypothesis development, research methodology, discussion and results, and ends with a conclusion.

\section{Agency Theory}

The interaction between principal and agent is portrayed in the agency theory. The fundamental problem is that the principal is unable to know exactly whether the agent's action has already aligned with the principal's interest or not [29], [46]. Information asymmetry became a common problem that happened between principal and agent, thus controlling activities is needed to reduce this problem [42]. At least, there are two things that might cause the agency problem: the separation of ownership and management [46], [67], and conflict of interests between controlling and non-controlling shareholders [49]. The emergence of the two agency problems might make the manager to not act in line with the owner's interest or desire. Manager and owner could have different behaviour in dealing with risk [29]. Therefore, according to [30], the owner could do the monitoring activity so that the manager's act could align with the owner's interest.

Another perspective based on [46], it is not only the owner who have the motivation to do the monitoring, else, the manager also has the motivation to convince the owner that what he does has already aligned with the owner's interest [46], [80]. The owner could make an investment in the information system for the reporting procedures as the means to monitor the manager's real behaviour [29]. The manager itself could provide sufficient information on the financial statement to convince the shareholders that the taken activities by the management have already aligned with the shareholder's goals, which in the end could reduce the monitoring costs [2], [42], [48]. To solve the information asymmetry problem as the impact from the interaction between management and share 
holders, the management side must provide a good quality financial statement which can inform the taken actions from the management [4], [9]. Adequate disclosure could reduce agency costs [46].

\section{Stakeholder Theory}

According to stakeholder theory, firm goals could be achieved if the firm can fulfil the stakeholder's interests [34]. Not only responsible to the stakeholders, a firm should also take attention to the different interests of all the stakeholders which might influence the firm from achieving its goals [34]. A firm's goal could be achieved because of the important role of the stakeholders. Therefore, a firm should take an action to achieve the shareholder's wishes which have the power to influence the firm's performance [25]. A firm should also give attention to all the taken actions which might bring effect to the stakeholders as the party who have interests [81]. Aligned with the disclosure practice, a firm has a responsibility to disclose the information to convince the stakeholders that the taken actions are aligned with the rules [52].

\section{Signalling Theory}

Signalling theory discusses a signal given from a firm to the other parties. In this theory, the signal means a firm's action that indicating the intention, motive, and firm's goals, whether it is directly or indirectly [63], [72]. The communication about the firm's performance or value is a positive signal that is given by the firm to convince the financial statement user party [17].

Signaling theory answers the information asymmetry problem [3], [51], [56], [66]. Information asymmetry problem could be reduced with the way a firm provides the information to the investors or capital market. Means that the management is providing the information to the investors to ease the investors to take an investment decision and reduce uncertainty [7], [17], [53]. A signal which has a positive impression that reflects a good firm's performance could attract investors interest, so the firm reputation could have an improvement [76].

\section{PSAK 69}

PSAK 69 is applied since January 1, 2018, and aims to control the accounting behaviour for the agriculture activities. Based on PSAK 69 [64] paragraph 5, a biological asset is an animal or a living plant. Aligning it with the asset, so the biological asset can be defined as crops or livestock owned by a firm from its past activity and have a future economic benefit. Biological asset is one of the assets used in agricultural activities. Agricultural activity is biological transformation management and biological asset harvest by entities to be sold or converted into an agricultural product or as an added biological asset [64].

The scope of PSAK 69 is the record about various things related with agriculture activities, such as (a) biological asset, except bearer plants; (b) agriculture products in harvest point; and (c) government's grant that is covered on paragraph 34 and 45. PSAK 69 also regulates the accounting treatments for biological asset starting from the growing process, degeneration, production and procreation.

Biological asset activity is measured on the initial recognition and on each end periods of financial reporting with the fair value minus the selling cost, similar with the agriculture product in the harvest time with the fair value minus selling cost. The disclosure of biological asset or agriculture product can only be done by an entity when the entity controls or has control towards the asset which comes from past activities. A firm must provide the disclosure regarding the total profit and loss within the ongoing period towards the initial recognition of a biological asset and the product from the agricultural product also from the subtraction between the changes of the fair value with the cost estimation on the biological asset sales. Besides, a firm's financial statement must also display the description or definition of each biological asset groups [64].

\section{Hypothesis Development}

Leverage can be described as a firm's financial structure that measures the long-term risk contained in the structure [79]. Leverage ratio is a proxy to measure the financial risk in a firm [13]. PSAK 69 paragraph 49 (a), regulates the disclosure of the existence and the recorded amount of biological asset with limited ownership and recorded the amount of biological asset that is guaranteed for the liability. Meanwhile, PSAK 69 paragraph 49 (c) regulates the disclosure of financial risk management strategy which is related to the agriculture activity. This disclosure could describe the financial risk faced by a firm.

According to the agency theory, agency costs, and monitoring costs could emerge not only in the relationship between manager and owner, controlling and non-controlling owners, but it can also happen in the relationship between the manager party and the creditor party [46], [80]. The bigger the debts rate, the bigger the different interests 
between the manager and creditor, and thus the bigger the monitoring cost too [5], [10], [46], [58], [59]. The improvement in the level of disclosure could reduce the monitoring costs [55] and lessen the chance of different interest between manager and creditor occurring.

The disclosure of information could give the creditors certainty in which their interests could be fulfilled by the firm [39]. Therefore, a firm with a high level of leverage tends to disclose more information to reduce the agency costs [10], [79] so that the information asymmetry between manager and creditor could be minimalized and reduced.

Several previous studies are aligning the leverage with the disclosure, whether it is generally or specifically and has already found various proof. Research [27], [35], [59] aligns leverage with the disclosure of intangible asset and finds a positive and significant relationship. However, research [5], [45], and [60] proves that there is no significant relationship between leverage and the disclosure of intangible asset.

Related with intellectual capital disclosure, research [11], [32] finds a positive relationship between leverage and intellectual capital disclosure. On the other hand, research [65], [82] proves that there is no influence between leverage and intellectual capital disclosure.

$\mathrm{H}_{1}$ : Leverage gives a positive influence on the biological asset disclosure

According to PSAK 69, an entity must disclose the combined profits and losses between the ongoing period on the initial recognition of a biological asset and agriculture product and from the change of fair value minus the cost to sell the biological asset (paragraph 40) and profits or loss that occurs from the changes of fair value minus the selling cost (50a). The disclosure of profits and loss could give a clear display of the firm's profit so it can help the investor and the other financial statement users to assess the firm's performance [75]. Research [69], argues that a manager in a firm with a high-profit margin and high economic profitability will be motivated to disclose more detailed information. The is because the management wants to give adequate certainty to the investors in which the firm can generate profits, so it can improve the compensation towards the manager.

Based on the point of view from agency theory, a firm with high profitability will disclose more information in detail as an effort to maintain the position and compensation arrangements [45]. The management will disclose more information if there is more good news than bad news [57]. Based on the signalling theory, a disclosure gives a positive signal that can strengthen the stock price and the firm's value [33], and also it can increase managers' compensation [69]. Besides, the information disclosed by a firm which experiences profits could also increase public trusts [5]. Therefore, the information will be disclosed more by the firm to the investor when the firm's performance is good or generates high profits [45], [79]. However, a different opinion is stated by [50], which states that the amount of profitability or firm's performance could raise or even lower the level of disclosure. Research [50] proves that a firm will disclose more if that firm has low profitability or even having a loss to reduce the occurrence of legal obligations.

In the research [20], [39], [69] they conclude that there is a positive correlation between profitability with the level of disclosure. However, in the research [5], [10], [16], [45] and [77] they conclude that profitability is not significantly influencing the disclosure. Research [8], [60], finds that profitability is not influencing the intangible asset disclosure. Research [55] and [65] finds that there is no correlation between profitability and intellectual capital disclosure. Specifically, if it is aligned with biological asset disclosure, [28], and [37] shows that profitability does not influence biological asset disclosure. This research then formulated the following hypothesis:

$\mathrm{H}_{2}$ : Profitability gives a positive influence on the biological asset disclosure

Liquidity shows how big a firm can fulfil their responsibility. The level of liquidity ratio is to be aligned with the level of a firm's capability to fulfil its long-term responsibility [79]. A firm is stated to have a good level of liquidity if the current asset level is bigger than the short-term responsibility. PSAK 69 paragraph 49 (a) regulates the existence disclosure and the recorded amount of biological asset that is guaranteed for liability. This disclosure gives a clear display of the liquidity level of agriculture firms.

Referring to the signalling theory, it can be concluded that there is a linear correlation between liquidity and information disclosure contained in the financial statement. It means that high-level liquidity is followed with high-level information disclosure too. It happens because a firm gives a positive signal to the investor regarding their good financial position [18]. However, agency theory has a different perspective. The higher the agency costs, the lower the liquidity level [46]. Thus, to minimalize the information asymmetry, a firm which has a low liquidity ratio will voluntarily give or disclose more information to justify its liquidity position, because a low liquidity level reflects the high debt in the firm capital structure [46], [77].

In the research [77], proves that liquidity has a significant negative influence on disclosure. Meanwhile, the research of [10], concludes that there is no significant relationship between liquidity and disclosure. 
Research [65] also finds that liquidity does not influence intellectual capital disclosure. This research tries to link liquidity with biological asset disclosure by formulating the following hypothesis:

$\mathrm{H}_{3}$ : Liquidity gives a positive influence on the biological asset disclosure.

Firm's growth shows how good a firm in maintaining its financial performance. A firm's growth can be shown in the improvement in the number of sales within a firm. A firm that has experienced growth has a potential opportunity to increase the firm's size [47] and increase profit [1]. The growth level of a firm could influence management's decision [22]. According to the stakeholder theory, a firm could develop if the firm can fulfil the stakeholder's interest [34]. For stakeholders to know that their interest has been fulfilled, a firm should do adequate information disclosure. The management will choose to disclose more information if the firm ever experiences growth to fulfil the stakeholder's interest [40], [60].

However, [82] has a different take, a firm which is new in the stock exchange listing will be more motivated to do information disclosure to attract investors. It means the lower a firm's growth, the higher its disclosure level. Another perspective is stated by [73] which concludes that a firm with a low growth level will choose to not undergo the disclosure regarding the intellectual capital in the financial statement. There is still no research that specifically tests the influence of a firm's growth on biological asset disclosure. This research is then formulating the following hypothesis:

$\mathrm{H}_{4}$ : Firm's growth gives a positive influence on the biological asset disclosure

Biological asset intensity shows the investment amount of a firm for the biological asset ownership. Agriculture firms must disclose the description about each group of biological assets owned [64] and the size or non-financial estimation from the specific quantity of each group of biological assets owned by entities on the end period PSAK 69 paragraph 46 (b) (i). This biological asset is measured on the initial recognition and each of the end reporting period on the fair value minus selling cost, except for the fair value that can't be measured reliably. The fair value method can measure the biological asset with an update and is closer to reality while increasing the value from the biological asset because of the biological transformation [21]. As for the result, the disclosed information in the financial statement can be increased in quality [68], [70]. According to the stakeholder's theory, all interested parties have the rights to receive information regarding the firm related to them [25]. The disclosure about the description and the size of the biological asset in the financial statement will bring an impact to the financial statement users on making a decision. A financial statement that is not disclosing the description and the size of the biological asset will make the financial statement useless [75].

Several studies state that the asset size or amount is increasing following the increase in the element number. Research [6], [36], [43] finds that a non-financial asset has a positive influence on the goodwill impairment disclosure. Meanwhile, if it is linked with the biological asset research [28], [37], [38], and [83] concludes that the biological asset intensity has a positive influence to the firm's biological asset disclosure. Thus, the following hypothesis is formulated:

$\mathrm{H}_{5}$ : Biological asset intensity gives a positive influence on the biological asset disclosure

A firm's size shows how big a firm scale that can be reflected in the amount of ownership of total assets [14]. The bigger the total owned asset, the bigger the firm's size. The amount of biological asset is a part of the total asset that is owned by a firm. The bigger the owned biological asset, the bigger the asset amount owned by the firm. In the financial statement, agriculture firms must include information about the description disclosure of each group of the owned biological asset [PSAK paragraph 40] and the size or non-financial estimation from the specific quantity of each group of the biological asset owned by entities in the end period [64] paragraph 46 (b) (i).

Research [71] states that a large scale firm is more motivated to disclose the information in the financial statement. As well as [79], which states that a large scale 'go public' firm can give information as a means to minimalize the financial performance uncertainty level so that the share capabilities to be traded is higher. If a large scale firm does not give detailed information disclosure, it will indicate bad news that can influence the firm's value [54].

Research [79] adds that a large scale firm will spend less cost to provides voluntary disclosure rather than the small scale firm.

For small scale firm, the budget spent on the disclosure in the financial statement will be bigger than the obtained benefits, so the small firms will do less disclosure [31], [50]. According to [45], there are several causes as to why large firms tend to disclose more data than small scale firms. It is because the large scale firms' managements have realized that several benefits can be obtained from the disclosure, such as having an ease of funding and bigger 
marketability; the accumulation and the disclosure cost of information spend by the firm is also not as big as the small firm. Furthermore, small firms also assume that information disclosure can put their competition in the market in a dangerous position.

Based on the agency theory, a big firm have bigger outside capital percentage. The agency costs rate (monitoring costs) will also raise following the total of outside capital. Information disclosure could minimalize agency costs, minimalize the information asymmetry between management and investors or shareholders, and also reduce the political costs [22], [26], [45], [46]. Thus, a large scale firm tends to disclose more detailed information in its financial statement [10], [15], [26]. Research [27] concludes that a firm's size gives a positive influence on the intangible asset disclosure level. Research [65] also finds a positive relationship between a firm's size with intellectual capital disclosure. Research [28], [37], [38], and [83] finds that there is a positive correlation between a firm's size with biological asset disclosure. Thus, the following hypothesis is formulated:

$\mathrm{H}_{6}$ : A firm's size gives a positive influence on the biological asset disclosure

External auditor has an important role in checking the fairness of a firm's financial statement. The external auditor must ensure that the firm's financial statement has already met the valid financial accounting standard, including the disclosure level. Financial statement checking by the auditor is one of the ways to reduce the agency costs [8], [46], and improve the disclosure credibility. To reduce the agency costs and improve the disclosure credibility, a firm should choose an auditor that has a good reputation. The better the auditor's reputation, the higher the obediency level towards the financial accounting standards [36] and also the higher the level of disclosure in the financial statement [36]. Other than that, the level of a big auditor's independence is higher than a small auditor, in which may enable the big auditor to give a strong effect to the firm's financial statement [24], [62]. If it is linked with the signalling theory, the disclosed information in the audited financial statement by the big auditor will give a positive signal and increase the trusts of external parties regarding the firm's financial statement [45].

External auditors face major challenges when it comes to ensuring that agricultural companies have already adhered to the application of IAS 41 regarding biological assets. It is because of the unique and specific nature of the biological asset and agriculture company operational activities [75]. The external auditor must have sufficient confidence that the fair value measurement method for the biological asset has already been disclosed following the IAS 41 [75]. The users of a financial statement are relying on the perception of the auditor and the obediency level received by the auditor for the obediency of agriculture companies on the financial accounting standards about biological assets [75].

Several studies have already linked auditor type with disclosure, in which [82] finds that a firm that has been audited with the big 4 audit office will do more intellectual capital disclosure rather than a company that is audited by the small auditor. On the other hand, [8] and [65] finds that there is no relationship between auditor type with the intangible asset disclosure. Several studies linked it with biological asset disclosure. Research [28] and [37] does not found the relationship between auditor type and biological asset disclosure. Meanwhile, [83] makes a conclusion in which there is a negative influence between auditor type and biological asset disclosure. This research is then formulated the following hypothesis:

$\mathrm{H}_{7}$ : Auditor's type gives a positive influence on biological asset disclosure

Listing status shows where a firm trades its shares. A firm could do shares trade not only in one country but in several countries. PSAK 69 paragraph 50 (f) requires agricultural companies to disclose the net exchange differences arising from the translation of financial statements into different presentation currencies, and the translation of foreign business activities into the reporting entity's presentation currency. This means that agricultural companies conducting foreign trade or listing abroad must comply with the disclosure rules of PSAK 69.

A firm that is operated in several countries must provide a more complete disclosure because the firm's activities have a high complexity [18]. The level of disclosure could be influenced by the level of a firm's activity abroad [6], [23], and listing status [6], [19]. Based on the signalling theory, the positive signal could be given by the firms to the stakeholders through the information disclosure in the financial statement. The level of disclosure could be much higher if a firm does an activity abroad. A manager in which the firm has an activity in the different country or trades its shares in the international stock exchange will give more disclosure as a way to shows the firm's position or performance to the stakeholders in the international level [26].

Research [6], [19], [23] finds a positive influence between the level of disclosure with the listing status. On the other hand, research [8] and [60] concludes that listing status does not influence 
the intangible asset disclosure. This finding is then strengthened by [37] who finds that the listing status does not influence the biological asset disclosure. Thus, the following hypothesis is formulated in this research:

$\mathrm{H}_{8}$ : Listing status gives a positive influence on the biological asset disclosure

\section{RESEARCH METHOD}

From the result of the purposive sampling with the defined criteria, 15 agriculture companies listed on the Indonesia Stock Exchange in the research period of 2016 - 2018 are obtained as the research samples.

The research variables/objects consist of the dependent variable, which is the biological asset disclosure (Y), and independent variables, which are leverage, profitability, liquidity, firm's growth, biological asset intensity, firm's size, auditor type, and listing status. The operational definition and research objects measurement are provided in table 2 .

Table 1. Samples Selection Criterion

\begin{tabular}{clc}
\hline \multicolumn{1}{c}{ Description } & Total \\
\hline 1 & $\begin{array}{l}\text { Agriculture firms listed on } \\
\text { Indonesia Stock Exchange } \\
\text { (IDX) between 2016-2018 }\end{array}$ & 24 \\
\hline 2 & $\begin{array}{l}\text { Firms that are not publishing } \\
\text { the complete financial } \\
\text { statement between 2016 and } \\
2018\end{array}$ & $(4)$ \\
\hline 3 & $\begin{array}{l}\text { Firms that are not applying } \\
\text { PSAK 69 }\end{array}$ & $(4)$ \\
\hline 4 & $\begin{array}{l}\text { Firms that are not using rupiah } \\
\text { currency as the reported } \\
\text { currency }\end{array}$ & $(1)$ \\
\hline & Total samples & 15 \\
\hline
\end{tabular}

Table 2. Definition of Operational and Measurement Variables

\begin{tabular}{cl}
\hline $\begin{array}{c}\text { Research } \\
\text { Variable }\end{array}$ & $\begin{array}{c}\text { Definition of Operational and } \\
\text { Measurement Variables }\end{array}$ \\
\hline $\begin{array}{c}\text { Biological asset } \\
\text { disclosure (Y) }\end{array}$ & $\begin{array}{l}\text { Economic information } \\
\text { communication by the firms in the } \\
\text { form of financial, non-financial, } \\
\text { quantitative, as well as other } \\
\text { information which reflects the } \\
\text { firm's performance and position } \\
{[62] .}\end{array}$ \\
& $\begin{array}{l}\text { Wallace Index }=\frac{n}{k} \\
\text { Notes: } \\
\text { n: jumlah butir kelengkapan yang } \\
\text { dipenuhi } \\
\mathrm{k}: \text { jumlah semua butir yang } \\
\text { mungkin dipenuhi }\end{array}$ \\
\hline
\end{tabular}

\begin{tabular}{|c|c|}
\hline & $\begin{array}{l}\text { Based on the } 40 \text { criteria of the } \\
\text { biological asset disclosure in PSAK } \\
69\end{array}$ \\
\hline Leverage (X1) & $\begin{array}{l}\text { The firm's financial structure in } \\
\text { measuring the long-term risk } \\
\text { contained in the financial structure } \\
\text { [79]. } \\
\text { DER }=\frac{\text { Total Debt }}{\text { Total Assets }}\end{array}$ \\
\hline $\begin{array}{l}\text { Profitability } \\
\text { (X2) }\end{array}$ & $\begin{array}{l}\text { A firm's capability to generate } \\
\text { profits or in other words as the } \\
\text { achieved net profit by the firm [75]. } \\
\text { ROE } \\
=\frac{\text { Net Profit }}{\text { Total Shareholder'fund }} \times 100 \%\end{array}$ \\
\hline Liquidity (X3) & $\begin{array}{l}\text { A firm's capability to fulfil its long- } \\
\text { term capability [79]. } \\
\text { Liq }=\frac{\text { Current Asset }}{\text { Current Liabilities }} \times 100 \%\end{array}$ \\
\hline $\begin{array}{c}\text { Firm's Growth } \\
\text { (X4) }\end{array}$ & $\begin{array}{l}\text { A firm's growth illustrates how } \\
\text { good a firm can maintain its } \\
\text { financial performance, it is shown } \\
\text { from the improvement of the sales } \\
\text { number in a firm [44]. } \\
\text { Potential Growth } \\
=\frac{\text { Sales } \mathrm{t}-\text { Sales } \mathrm{t}-1}{\text { Sales } \mathrm{t}-1}\end{array}$ \\
\hline $\begin{array}{l}\text { Biological Asset } \\
\text { Intensity (X5) }\end{array}$ & $\begin{array}{l}\text { Shows the invested amount of a } \\
\text { firm for the biological asset } \\
\text { ownership [37], [38]. } \\
I A B=\frac{\text { Biological Asset }}{\text { Total Aset }}\end{array}$ \\
\hline Firm size (X6) & $\begin{array}{l}\text { Shows a firm's scale that is } \\
\text { reflected in the total asset } \\
\text { ownership amount [14]. } \\
\text { Size : Log (Total asset) }\end{array}$ \\
\hline $\begin{array}{c}\text { Auditor Type } \\
\text { (X7) }\end{array}$ & $\begin{array}{l}\text { The auditor credibility of the } \\
\text { accountant firm with a very good } \\
\text { reputation [37], [38]. } \\
1=\text { Audited by the big } 4 \\
0=\text { Audited by the non-big } 4\end{array}$ \\
\hline $\begin{array}{l}\text { Listing Status } \\
\text { (X8) }\end{array}$ & $\begin{array}{l}\text { A place in which a firm does the } \\
\text { stock trades, whether it is in one } \\
\text { country or several countries [38]. } \\
1=\text { Listed in more than } 1 \text { stock } \\
\text { exchange } \\
0=\text { Listed in } 1 \text { stock exchange }\end{array}$ \\
\hline
\end{tabular}

The research model is using the multiple linear regression to test the hypothesis as described below:

$$
\begin{aligned}
\text { DISCit }= & \beta 0+\beta 1 \text { LEVit }+\beta 2 \text { ROEit }+\beta 3 \text { LIQit } \\
& +\beta 4 \text { PGit }+\beta 5 \text { BAIit }+\beta 6 \text { FZit }+\beta 7 \text { KAPit } \\
& +\beta 8 \text { LSit }+ \text { eit }
\end{aligned}
$$

\section{RESULTS AND DISCUSSION}

The data analysis results empirically show the descriptive analysis illustration and the result of the multiple linear regression analysis which are shown in table 3 and 4. 
Table 4 provides the $\mathrm{R}$ square $\left(\mathrm{R}^{2}\right)$ which amounts to 0.313 , with the model is statistically significant from the $\mathrm{p}<0.05$. It means the independent variable (leverage, profitability, liquidity, firm's growth, biological asset intensity, firm's size, auditor type, and listing status) only have 31.3\% effect on the dependent variable (biological asset disclosure). The rest of it, $68.7 \%$, can be influenced by other factors outside the research model.

Table 3. Descriptive Statistic Analysis Result

\begin{tabular}{lrrrr}
\hline Variable & $\begin{array}{c}\text { Mini- } \\
\text { mum }\end{array}$ & $\begin{array}{c}\text { Maxi- } \\
\text { mum }\end{array}$ & Mean & $\begin{array}{c}\text { Std. } \\
\text { Deviation }\end{array}$ \\
\hline $\begin{array}{l}\text { Disclosure } \\
\text { (Y) }\end{array}$ & .2000 & .6667 & .419259 & .1102085 \\
\hline LEV & .1460 & 1.2541 & .574519 & .2722042 \\
ROE & -9.7908 & 3.7984 & .003098 & 1.6859541 \\
LIQ & .1126 & 6.7720 & 1.710445 & 1.7323592 \\
P/G & .1865 & 11.1869 & 1.583393 & 1.7432643 \\
BAI & .0026 & .6664 & .321598 & .2027733 \\
FZ & 28.3204 & 31.1768 & 29.853681 & .8232218 \\
KAP & .0 & 1.0 & .600 & .4954 \\
& & & & \\
\hline Kolmogorov- & -1.807 & & \\
Smirnov Z & & & & \\
\hline Run Test Asymp. & 0.071 & & \\
Sig. (2-tailed) & & & & \\
\hline
\end{tabular}

Table 4. Multiple Linear Regression Analysis Result

\begin{tabular}{|c|c|c|c|c|}
\hline Model & $\begin{array}{l}\text { Unstandar- } \\
\text { dized } \\
\text { Coefficients } \\
\text { B }\end{array}$ & $\begin{array}{c}\text { Std. } \\
\text { Err } \\
\text { or }\end{array}$ & $\mathbf{T}$ & Sig \\
\hline (Constant) & -.168 & .739 & -.228 & .821 \\
\hline Leverage (LEV) & .030 & .114 & .266 & .791 \\
\hline Profitability (ROE) & .015 & .016 & .926 & .361 \\
\hline Liquidity (LIQ) & .008 & .016 & .515 & .609 \\
\hline Firm's Growth (PG) & .004 & .018 & .206 & .838 \\
\hline Biological Asset & .264 & .110 & 2.391 & .022 \\
\hline \multicolumn{5}{|l|}{ Intensity (BAI) } \\
\hline Firm Size (FZ) & .015 & .024 & .618 & .541 \\
\hline Auditor Type (KAP) & .058 & .041 & 1.415 & .166 \\
\hline Listing Status (LS) & -.040 & .065 & -.617 & .541 \\
\hline $\mathrm{R}^{2}$ & .313 & & & \\
\hline $\mathrm{R}$ & .559 & & & \\
\hline
\end{tabular}

The first hypothesis results show that leverage has no significant effect on biological asset disclosure. This result is not aligned with the research of [58]. Williams, 2001, [27], [35], [59] which concludes that the leverage gives a significant and positive influence on the intangible asset disclosure. This test result is also not aligned with the research of [1]], which finds that there is a positive relationship between leverage and the intellectual capital disclosure. However, this research is aligned with the research of [5], [45], [60] which concludes that leverage does not give a significant effect to the intangible asset disclosure. This research also supports [65], [82] which proves that there is no effect between leverage and intellectual capital disclosure. This research results show that the amount of leverage is not influencing the amount of disclosed information regarding the biological asset by an agriculture firm. An agriculture firm must obey the PSAK 69 paragraph 49 (a) about the existence disclosure and the recorded amount of biological asset in which the ownership is limited, and the recorded amount of guaranteed biological asset for the liability, also PSAK 69 paragraph 49 (c) about the disclosure of financial risk management strategy related with the agriculture activities. From the existing 15 firms in this research, as much as 5 firms are having a low level of leverage, meanwhile, 10 of them are having a high level of leverage.

Another interesting finding is collected from the data analysis result, all five firms with low leverage level do not conduct the biological asset disclosure as regulated in PSAK 69. From the 10 firms which have high leverage level, only 5 of them do the biological asset disclosure as regulated in PSAK 69. It proves that the amount of leverage in an agriculture firm does not influence the biological asset disclosure. A firm with high leverage disclose its biological asset to reduce monitoring costs, agency costs, and information asymmetry between manager and the creditors [5], [10], [39], [46], [58], [59], [79]. On the other hand, the firm with high leverage that is not disclosing its biological asset considers the financial risk that might be faced in the future which might influence the investor or creditor. The more risk a firm has, the higher the reward that the investor or creditor could ask for.

The second hypothesis testing shows that profitability does not give a positive influence on the biological asset disclosure. This result is not aligned with [20], [39], [69] which concludes that profitability gives a positive influence to the disclosure level. However, this research shares the same idea with [5], [10], [16], [45], and [77] which finds that profitability does not have a significant influence on the disclosure. The research [8] and [60] also concludes that profitability does not influence the intangible asset disclosure. This research result also supports the research [65] which finds that profitability does not influence intellectual capital disclosure. In the research result, [28] and [37] also find that profitability does not influence biological asset disclosure. It means that the amount of profitability owned by an agriculture firm does not influence the firm to increase or decrease the level of its biological asset disclosure in the financial statement. This result is different from the agency theory and signalling theory [5], [33], [45], [57], [79] which states that profitability gives a positive 
influence to the disclosure. 6 firms in this research have low profitability, while the other 9 have high profitability. From the 9 firms with high profitability, 5 of them are not conducting the biological asset disclosure based on the PSAK 69. It happens because of the complexity of the biological asset disclosure which is measured with the fair value method. Although the 6 firms have low profitability, these 6 firms are still conducting the biological asset disclosure based on the PSAK 69 paragraph 40 and 50 (a) about the loss or profit occurred from the biological asset. It shows that the low level of profitability does not prevent a firm from conducting the biological asset disclosure because a firm tries to give a real portrait to the external party to avoid law obligations in the future and shows the firm's effort to obey the PSAK 69. This condition aligns with the opinion from [50] which states that a firm with low profitability still has a motivation to do a disclosure.

The third hypothesis testing shows that liquidity does not have a positive influence on the biological asset disclosure. These findings are not in line with [77] which proves that liquidity gives a significant and negative influence on the disclosure. However, this research result corresponds with [10] and [79] which finds that there is no significant relationship between liquidity and disclosure. This result has also supported the research [65] which concludes that liquidity does not influence intellectual capital disclosure. The level of biologic asset disclosure in an agriculture firm is not influenced by the level of liquidity owned by a firm. The empirical data shows that the 7 agriculture firms in this research have either higher liquidity level or bigger current asset than the current liabilities. Meanwhile, the other 8 agriculture firms have low liquidity. Interestingly, there is no difference in the level of biological asset disclosure between a firm with high liquidity and a firm with low liquidity. The five firms from a total of 8 firms which are having low liquidity show the obediency level to the PSAK 69 with conducting the biological asset disclosure. This is done by a firm to minimalize the occurrence of information asymmetry between the firm and the firm's creditor. Aligned with the agency theory which states that a firm with low liquidity would voluntarily disclose more information [46], [77]. Another interesting finding is shown with only 3 out of 8 firms with high liquidity conducting the biological disclosure. This finding is not being supported by the signalling theory which states that a high liquidity level is followed by a high level of information disclosure too [18].

The fourth hypothesis testing results show that a firm's growth does not influence the biological asset disclosure. This research result is different from [40], [60], and [73] which finds the positive relationship between the firm's growth with the level of disclosure. This research also contradicts [82] which concludes that there is a negative influence between growth and disclosure. The empirical data shows that 8 firms have high growth level and 7 firms that have low growth level. Both firms which have either high or low level of growth have the same level of obedience towards biological asset disclosure because all agriculture firms have the same goals: to increase their firm's growth to gain the stakeholders' trust and obtain additional funds.

The fifth hypothesis testing result shows that biological asset intensity has a positive influence on the biological asset disclosure. This result aligns with the research [6], [36], [43] which proves that the non-financial asset has a positive influence on goodwill impairment disclosure. This result supports the research [28], [37], [38], and [83] which concludes that biological asset intensity has a positive influence on the firm's biological asset disclosure. It shows that the higher the biological asset intensity, the higher the biological asset disclosure level too. The applied fair value method that is used to measure the biological asset could increase the value of the biological asset [21]. As the biological asset value goes higher, the firm tends to disclose more information regarding the biological asset to give more information for the stakeholders' decision making [25]. The firms are trying to make a useful financial statement that can portray reality by improving the disclosure regarding the biological asset description and size [75].

The sixth hypothesis testing concludes that the firm's size does not influence the biological asset disclosure. This research result does not support the research of [27] which finds that the firm's size has a positive influence on the level of intangible asset disclosure. This result is also not aligned with the research [65] which also finds that there is a positive relationship between the firm's size and the intellectual capital disclosure. The test result is also not aligned with the conclusion founded by [28], [37], [38], and [83] which concludes that there is a positive correlation between a firm's size and the biological asset disclosure. This research result is different with the opinions of [10], [15], [22], [26], [31], [45], [46], [50], [54], [71], [79], which states that large scale companies are more motivated to disclose the information in the financial statement to minimalize the level of financial performance uncertainty, improve the firm's value, the opportunity to gain fundings, bigger marketability, minimalize the agency costs, reduce the political cost, and minimalize the information asymmetry. If the number of the biological asset goes higher, then the total asset could go higher too. The empirical 
data shows that 7 out of 15 agriculture firms in this research are having a decrease in their total asset number. Interestingly, although there is a decrease, the firms are still conducting their biological asset disclosure. It means that the number of assets owned by an agriculture firm is not influencing the firm's motivation to conduct biological asset disclosure. This result could be linked with the characteristics of the biological asset. Biological asset is the animals or living plants which have a growth, degeneration, production, and procreation process. The value of the biological asset could experience uncertain changes. To reduce the uncertainty impact of financial performance and information asymmetry, some firms disclose information about the biological asset without considering the value of their assets.

The seventh hypothesis testing shows that the auditor type does not influence the biological asset disclosure. The research [82] shows that firms audited by the Big 4 audit firm disclose more intellectual capital than the firms audited by small audit firms. On the other hand, the research [8], [65], shows that there is no relationship between the auditor type and the intangible asset disclosure. There are several studies linked with biological asset disclosure. The research [28], [37], has not found the relationship between auditor type with the biological asset disclosure. Meanwhile, [83] concludes that there is a negative influence between the auditor type and the biological asset disclosure. There are several reasons which could be linked with the zero influence that the auditor's types have on biological asset disclosure in this research The first is that 9 out of 15 , or around $60 \%$, of the agriculture firms in this research, have already been audited by the Big 4 accountant firms. Second, there is no significant difference in the level of biological asset disclosure conducted by a firm that has been audited by both the Big 4 and non-Big 4 accountant firms. The third reason is that the checking of the biological asset disclosure obediency based on the PSAK 69 is influenced by the audit judgment. These become the reason on why the checking of the biological asset disclosure obediency becomes more complex for auditors.

The eight hypothesis testing results show that the listing status does not influence the biological asset disclosure. This result does not align with the research [6], [19], [23] which shows that listing status gives a positive influence to the disclosure level. On the other hand, this hypothesis testing results correspond with the testing conducted by [8] and [60] which shows that listing status does not have any influence on the intangible asset disclosure.
This finding also supports the research by [37] which concludes that listing status does not influence biological asset disclosure. Several things caused this testing result. First, there are only 3 firms that do the listing on the international stock exchange. Second, 11 agriculture firms that are only being listed in the Indonesia Stock Exchange are still showing obediency to the biological asset disclosure. Third, there is a practice of PSAK 69 which is already based on the IAS 41, so there is no difference in the financial accounting standards between Indonesia and the international accounting standards.

\section{CONCLUSION}

The practice of PSAK 69 about the biological asset, the biological asset disclosure becomes important to be discussed. This research is testing the effect of leverage, profitability, liquidity, firm's growth, biological asset intensity, firm size, auditor type, and listing status towards the biological asset disclosure on agriculture firms that are listed on Indonesia Stock Exchange (IDX) between 2016 and 2018. Biological asset intensity is proven to influence biological asset disclosure. It corresponds with the agency theory and stakeholder theory. Interestingly, leverage, profitability, liquidity, firm's growth, firm size, auditor type, and listing status are not influencing biological asset disclosure.

This research has been attempted and conducted following the scientific procedures, however, it still has some limitations such as the subjectivity on deciding the PSAK 69 paragraph which must be grouped and representing one item index, thus, the assessment is being treated following the best assessment conducted by the researcher. In the future, this research can be conducted while considering other variables which are some of the factors on the biological asset disclosure, for example, good corporate governance such as audit committee, the board of commissioners, the board of directors, and other aspects from good corporate governance.

This research contributes to widening the perspective on firm's characteristic that can increase firms' intention and motivation on disclosing the information about biological asset based on PSAK 69. Therefore, this research is useful for the regulators, accounting standards makers, firms, and shareholders that have interests in information disclosure, especially biological asset disclosure.

\section{REFERENCES}

[1] Abeysekera, I. (2011). The Relation of Intellectual capital Disclosure Strategies and Market Value in Two Political Settings. Journal of Intellectual capital, 12(2), 319-338. 
[2] Abraham, S., and Cox, P. (2007). Analysing the determinants of narrative risk information in UK FTSE 100 annual reports. The British Accounting Review, 39(3), 227-248.

[3] Akerlof, G. A. (1970). The Market For 'Lemons': Quality Uncertainty And The Market Mechanism. The Quarterly Journal Of Economics, 84(3), 488-500. Retrieved from http://dx.doi. org/10.2307/1879431

[4] Ali, A., and Hwang, L. (2000). Country-specific factors related to financial reporting and the value relevance of accounting data. Journal of Accounting Research, 38(1), 1-21.

[5] Alsaeed, K. (2006). The Association Between Firm-Specific Characteristics And Disclosure: The Case Of Saudi Arabia. Managerial Auditing Journal, 21(5), 476-496. Retrieved from http://dx.doi.org/10.1108/02686900610667256

[6] Amiraslani, H., Iatridis, G., and Pope, P. (2013). Accounting for asset impairment: a test for IFRS compliance across Europe.

[7] Awuy Vinta P, Sayekti Y, dan Purnamawati I. (2016). Pengaruh Pengungkapan Corporate Social Responsibility (CSR) Terhadap Earnings Response Coefficient (ERC) (Suatu Studi Empiris Pada Perusahaan Pertambangan yang Terdaftar di Bursa Efek Indonesia Pada Tahun 2010-2013). Jurnal Akuntansi dan Keuangan, 18(1), 15-26. DOI: 10.9744/jak. 18.1.15-26

[8] Azevedo, G., Oliveira, J., and Couto, M. A. F. (2019). Compliance with intangible assets disclosure requirements: study of Portuguese non-financial companies. Contaduríay administración, 64(4), 8.

[9] Ball, R., Kothari, and Robin, A. (2000). The effect of international institutional factors on properties of accounting earnings. Journal of Accounting and Economics, 29(1), 1-51.

[10] Barako, D. G., Hancock, P., and Izan, H. Y. (2006). Factors Influencing Voluntary Corporate Disclosure by Kenyan Companies. Corporate Governance an International Review, 14(2), 107-125.

[11] Boujelbene, M. A., and Affes, H. (2013). The impact of intellectual capital disclosure on cost of equity capital: A case of French firms. Journal of Economics Finance and Administrative Science, 18(34), 45-53.

[12] BPS. (2019). Badan Pusat Statistik. Retrieved from https://www.bps.go.id/publication/2019/ 07/04/daac1ba18cae1e90706ee58a/statistik -indonesia-2019.html

[13] Brigham, F, E., dan Houston. Fundamental of Financial Management: Dasar-Dasar Manajemen Keuangan, Edisi 10, Salemba Empat., Jakarta, 2006.

[14] Brigham, dan Houston. Dasar-Dasar Manajemen Keuangan Buku 1, Edisi 11, Salemba Empat., Jakarta, 2010.
[15] Cairns, R., Harris, I., and Mak, T. (2011). Regulation of cancer cell metabolism. NCBI, 11(2), 85-95.

[16] Chau, G., and Gray, S. (2010). Family ownership, board independence and voluntary disclosure: Evidence from HongKong. Journal of International Accounting Auditing and Taxation, 19(2), 93-109.

[17] Connelly, B. L., Certo, S., and R. Duane Ireland, C. R. R. (2011). Signaling Theory: A Review and Assessment. Journal of Management, 37(1), 39-67. https://doi.org/10.1177\% 2F0149206310388419

[18] Cooke, T. E. (1989). Voluntary Corporate Disclosure by Swedish Companies. Journal of International Financial Management and Accounting, 1, 171-195.

[19] Cooke, T. E. (1992). The Impact of Size, stock Market Listing and Industry Type on Disclosure in the Annual Reports of Japanese Listed Corporation. Accounting and Bisiness Research, 22, 229-237.

[20] Courtenay, S. M., C.M., E., and Cheng. (2006). Board composition, regulatory regime and voluntary disclosure. The International Journal of Accounting, 41(3), 262-289.

[21] Cyril, U. M., Elizabeth, N. I., and Chukwuemeka, M. C. (2019). Impact of Fair Value Accounting on Biological Asets in Agricultural Sector in Nigeria. International Journal of Finance and Banking Research, 5(4), 64.

[22] Daniel, B., Wassell, S., and Gilligan, R. Child Development for Child Care and Protection Workers, 2nd edition, Jessica Kingsley Publishers., London, 2010.

[23] Daske, H., Hail, L., Leuz, C., and Verdi, R. (2013). Adopting a Label: Heterogeneity in the Economic Consequences around IAS/IFRS Adoptions. Journal of Accounting Research, 51, 495-547.

[24] DeAngelo, L. E. (1981a). Auditor independence, "low bailing", and disclosure regulation. Journal of Accounting and Economics, 113127.

[25] Deegan, C. Financial accounting theory. In McGraw-Hill Book Company., Sydney, 2004.

[26] Depoers, F. (2000). A cost benefit study of voluntary disclosure: some empirical evidence from French listed companies. European Accounting Review, 9(2), 245-263. https://doi. org/10.1080/09638180050129891

[27] Devalle, A., Rizzato, F., and Busso, D. (2016). Disclosure indexes and compliance with mandatory disclosure- The case of intangible asets in the Italian market. Advances in accounting, 35, 8-25.

[28] Duwu, M. I., D., S. C., dan A., H. N. (2018). Pengaruh Biological Aset Intensity, Ukuran Perusahaan, Konsentrasi Kepemilikan, Jenis KAP, dan Profitabilitas Terhadap Biological Aset Disclosure. Jurnal Akuntansi dan Keuangan Daerah, 13(2), 56-57. 
[29] Eisenhardt, K. M. (1989). Agency theory: An assessment and review. The Academy of Management Review, 14(1), 57-74.

[30] Fama, E. F., and Jensen, M. C. (1983). Separation of Ownership and Control. Journal of Law and Economics, 26, 301-325.

[31] Field, T., Hernandez-Reif, M., Diego, M., Schanberg, S., and Kuhn, C. (2005). Cortisol decreases and serotonin and dopamine increase following massage therapy. International Journal of Neuroscience, 115(10). https://doi.org/10.1080/00207450590956459

[32] Fischer, M., and Marsh, T. (2013). Biological asets: Financial Recognition And Reporting Using Us And International Accounting Guidance. Journal Of Accounting And Finance; West Palm Beach, 13, 57-74.

[33] Foster, M. J. (1986). The value of formal planning for strategic decisions: A comment. Journal Strategic Management. https://doi.org/ 10.1002/smj.4250070206

[34] Freeman, R. E., and Phillips, R. A. (2002). Stakeholder Theory: A Libertarian Defense. Business Ethics Quarterly, 12(3), 331-349

[35] Gerpott, T. J., Thomas, S. E., and Hoffmann, A. P. (2008). Intangible aset disclosure in the telecommunications industry. Journal of intellectual capital.

[36] Glaum M., Schmidt P., Street D L., and Vogel S. (2012). Compliance with IFRS 3 and IAS 36 Required Disclosures Across 17 European Countries: Company and Country Level Determinants. Accounting and Business Research, 43(3), 163-204. http://dx.doi.org/10.1080/000 14788.2012.711131

[37] Gonçalves, R., and Lopes, P. (2014). FirmSpecific Determinants of Agricultural Financial Reporting. Procedia - Social and Behavioral Sciences, 110, 470-481.

[38] Gonçalves, R., and Lopes, P. (2015). Accouting in Agriculture: Disclosure practices of listed firms. Contabilidade and Gestão: Portuguese Journal of Accounting and Management, (16), 9-44.

[39] Haniffa, R. M., and Cooke, T. E. (2002). Culture, Corporate Governance and Disclosure in Malaysian Corporations. Abacus, 38, 317-349.

[40] Hanifa, M. H., and Rashid, H. M. A. (2005). The Determinant of Voluntary Disclosures in Malaysia: The Case of Internet Financial Reporting. UNITAR E-Journal, 2(1), 22-42.

[41] Healy, P. M., and Palepu, K. G. (1993). The Effects of Firms' Disclosure Strategies on Stock Prices. Accounting Horizons, 7, 1-11.

[42] Healy, P. M., and Palepu, K. (2001). Information Asymmetry, Corporate Disclosure, And The Capital Markets: A Review Of The Empirical Disclosure Literature. Journal Of Accounting And Economics, 31(1), 405-440. Retrieved from http://dx.doi.org/10.1016/S01 654101(01)00018-0
[43] Heitzman, S., Wasley, C., and Zimmerman, J. (2010). The Joint Effects of Materiality Thresholds and Voluntary Disclosure Incentives on Firms' Disclosure Decisions. Journal of Accounting and Economics, 49(1), 109-132.

[44] Helfert, E. A. Teknis Analisis Keuangan: Petunjuk Praktik untuk Mengelola dan Mengukur Kinerja Perusahaan, PT Elex Media Komputindo., Jakarta, 1997.

[45] Inchausti, B. G. (1997). The influence of company characteristics and accounting regulation on information disclosed by Spanish firms. The European Accounting Review, 6(1), $45-68$.

[46] Jensen, M. C., and Meckling, W. H. (1976). Theory Of The Firm: Managerial Behavior, Agency costss And Ownership Structure. Journal of Financial Economics, 3(4), 303-360. Retrieved from http://dx.doi.org/10.1016/0304405x(76)90025-8

[47] Kallapur, S., and Trombley, M. (2001). The investment opportunity set: determinants, consequences and measurement. Managerial Finance, 27, 3-15.

[48] Khlifi, F., and Bouri, A. (2010). Corporate Disclosure and Firm characteristics: A Puzzling Relationship. Journal of Accounting, Business and Management (JABM), 17.

[49] La Porta, R., Lopez-De-Silanes, F., and Shleifer. (1999). Corporate Ownership Around the World. Journal of Finance, 54, 471-517. https://doi.org/https://doi.org/10.1111/0022108 2.00115

[50] Lang, M., and Lundholm, R. (1993). CrossSectional Determinants of Analyst Ratings of Corporate Disclosures. Journal of Accounting Research, 31, 246-271. https://doi.org/10.2307/ 2491273

[51] Levin, B. (2001). Energizing Teacher Education and Professional Development with Problem Based Learnig. (Beauregard St. Alexandria (USA): Association for Supervision and Curriculum Development.

[52] Magnan, I., and Farrell, O. (2004). CSR and Marketing: An Integrative Framework. Journal of the Academy of Marketing Science, 32(1), $1-19$.

[53] Mahoney, J. (2012). The Logic of Process Tracing Tests in the Social Sciences. Journal Sociological Methods and Research, 41(4), 570-597.

[54] McKinnon, J. L., and Dalimunthe, L. (1993). Voluntary disclosure of segment information by Australian diversified companies. Accounting and Finance, 33(1), 33-50. https://www. researchgate.net/deref/http\%3A\%2F\%2Fdx.do i.org\%2F10.1111\%2Fj.1467-629X.1993.tb001 92. $\mathrm{x}$

[55] Meek, Gray, M., Roberts, Clare, B., and Sidney, J. (1995). Facts Influencing Voluntary Annual Report Disclosures by US, UK and Continental 
European Multinational Corporations. Journal of International Business Studies, 96, 555572.

[56] Morris, R. D. (1987). Signaling, Agency Theory and Accounting Policy Choice. Accounting and Business Research, 18, 47-56.

[57] Naser, K. (1998). Comprehensiveness of disclosure of non-financial companies listed on the amman financial market. International Journal of Commerce and Management, 8(1), 88119.

[58] Naser K and Al-Khatib, K. (2000) Determinants of the Depth of Voluntary Disclosure in the Board of Directors' Statement in a Sample of Jordanian Listed Companies. Advances in International Accounting, 13, 99-118

[59] Naser, K., Al-Khatib, K., Karbhari, Y., (2002). Empirical Evidence on the Depth of Corporate Information Disclosure in Developing Countries: the Case of Jordan. International Journal on Corporate Management, 12(3 and 4), p. 122-152.

[60] Oliveira, L., Rodrigues, L., and Craig, R. (2006). Firm-Spesific Determinants of Intangibles Reporting: Evidence from the Portuguese Stock Market. Portuguese Stock Market, 10(1), 11-33.

[61] Ore, M. (2011). Problematic Aspects Of Accounting For Biological Asets. Proceedings Of The International, Scientific Conference. Production And Taxes. Jelgava: Vidzeme University Of Applied Sciences, 204-210. Retrieved from http://llufb.llu.lv/Index_En.Html

[62] Owusu-Ansah, S. (1998). The impact of corporate attributes on the extent of mandatory disclosure and reporting by listed companies in Zimbabwe. The International Journal of Accounting, 33(5), 605-631. https://doi.org/10. 1016/S0020-7063(98)90015-2

[63] Porter, M. E. Competitive Strategy Techniques for Analyzing Industries and Competitors, The Free Press., New York, 1980.

[64] PSAK 69. (2018). Pernyataan Standar Akuntansi Keuangan No. 69 tentang Agrikultur.

[65] Rep, A., Žager, K., and Oliveira, C. (2019). The Role of Firm characteristics in Voluntary Disclosure of IC Information and Its Importance for High-Tech Companies. Journal of Information and Organizational Sciences, 43(2), 185-209.

[66] Ross, S. A. (1977). The determination of financial structure: The incentive-signalling approach. The Bell Journal of Economics, 8(1), 2340. Retrieved from https://doi.org/10. 2307/ 3003485

[67] Shleifer, A., and Vishny, R. (1986). Large Shareholders and Corporate Control. Journal of Political Economy, 94, 461-488.

[68] Silva, M. W. K. P., Ranil, R. H. G., and Fonseka, R. M. (2012). Luffa cylindrica (L.) M. Roemer (Sponge Gourd-Niyan wetakolu): An emerging high potential underutilized cucurbit, 23(2), 186-191. http://dx.doi.org/10. 4038/tar.v23i2.4650

[69] Singhvi, S. S., and Desai, H. B. (1971). An Empirical Analysis Of The Quality Of Corporate Financial Disclosure. The Accounting Review, 46(1), 120-138.

[70] Sorolla García, J. (2019). Discussion on the valuation of biological asets: fair value vs. historical cost.

[71] Souissi, M., and Khlif, H. (2012). Meta-analytic review of disclosure level and cost of equity capital. International Journal of Accounting and Information Management, 20(1), 49-62.

[72] Spence, M. (1973). Job Market Signaling. The Quarterly Journal of Economics, 87, 355-374.

[73] Taliyang, S. M., Latif, R. A., and Mustafa, N. H. (2011). The Determinants of Intellectual capital Disclosure among Malaysian Listed Companies. International Journal of Management and Marketing Research, 4(3), 25-3

[74] Tarigan J dan Semuel H. (2014). Pengungkapan Sustainability Report dan Kinerja Keuangan. Jurnal Akuntansi dan Keuangan, 16(2), 88-101.

[75] Van Biljon, M. (2016). Anapplication guideline for the fair value accounting of biological asets, Doctoral dissertation, University of South Africa.

[76] Verrecchia, R. E. (1983). Discretionary disclosure. Journal of Accounting and Economics, 5, 179-194.

[77] Wallace, R. S. O., Naser, K. and Mora, A. (1994). The Relationship Between the Comprehensiveness of Corporate Annual Reports and Firm Specific Characteristics in Spain. Accounting and Business Research, 25, 41-53.

[78] Wardani, Rr Puruwita. (2012) Faktor-faktor yang Mempngaruhi Luas Pengungkapan Sukarela. Jurnal Akuntansi dan Keuangan, 14(1), 1-15.

[79] Watson, A., Shrives, P., and Marston, C. (2002). Voluntary Disclosure of Accounting Ratios in the UK. British Accounting Review, 34, 289-313.

[80] Watts, R. L., and Zimmerman, J. L. Positive Accounting Theory, 1986.

[81] Wicks, G. ., Crutcfield, D. A., and Burnside, O. C. (2004). Influence of Wheat (Triticum aestivum) Straw Mulch and Metalachlor on Corn (Zea mays) Growth an dYield. Weed Science, 42(1), 141-247.

[82] Whiting, R. H., and Woodcock, J. (2011). Firm characteristics and intellectual capital disclosure by Australian companies. Journal of Human Resource Costing and Accounting.

[83] Yurniwati, Djunid, A., and Amelia, F. (2018). Effect of Biological Aset Intensity, Company Size, Ownership Concentration, and Type Firm against Biological Asets Disclosure. The Indonesian Journal of Accounting Research, 21, 121-146. https://doi.org/10.33312/ijar.338. 